\title{
ТӨВ АЙМГИЙН БОР-УУЛЫН ПЕРЛИТИЙН ДУЛААНЫ ХӨӨЛТИЙН ГОРИМ
}

\author{
Ж.Оюунцэцэг, Н.Лхагва-Эрдэнэ, Л.Мандахсайхан, Р.Уламбаяр \\ ШУА, Хими, хими-технологийн хүрээлэн, иахим шуудан: ovuntsetsegj@yahoo.com
}

\begin{abstract}
The perlit from Bor-Uul deposit has been studied. We produced expended perlite by a heat expansion principle using a vertical stationary furnace at different conditions. The result showed that the perlite's expansion significantly depends on the temperature $\left(1050-1250^{\circ} \mathrm{C}\right)$, time of the heating (20-240sec) and the particle size. We have the first time obtained highly expanded perlite with an expansion coefficient equal to 964 be using the vertical furnace at our laboratory.
\end{abstract}

\section{Оршил}

Дотоод бүтэцдээ 2-5\% ус агуулсан галт уулын шилийг перлит гэнэ. Монгол оронд Элгэнбулаг, Замын-Улаан, Хөхтээг, Цахиур-Уул, Булган-Уул, Ухаа-Овоо зэрэг галт уулын гаралтай перлитийн 10 орчим орд байдаг. Өмнө судлагдаагүй перлитийн орд болох Төв аймгийн Баян сумын Бор-Уулын ордын перлитийг уг судалгаандаа ашиглав.

Перлитийг 870-1300 $\mathrm{C}$ температурт халаахад өөрийн бүтцэд агуулагдах усны нөлөөгөөр хөөж 2-20 дахин их эзлэхүүнтэй, сувд шиг гялгар цагаан өнгөтэй, сэвсгэр хөнгөн болдог. Тиймээс түүнийг сувдан чулуу гэдэг. Перлит нь найрлагандаа их хэмжээний натрийн ба калийн исэл агуулсан, мөн шиллэг бүтэцтэй учир нам температурт хайлдаг онцгой чанартай.

Хөөсөн перлитийн агаар агуулсан бөмбөлгүүд нь дуу, дулааныг тусгаарлах үндэс болдог. Мөн өөртөө олон төрлийн органик болон органик бус бодисыг ихээр шингээх чадвартай. Перлит нь хүн болон хүрээлэн буй орчинд сөрөг нөлөөгүй, аюулгүй, байгалийн цэвэр материалд тооцогддог.Түүхий болон хөөсөн перлитийн физик, химийн өвөрмөц шинж чанарыг ашиглан барилга, металлурги, хүнс, химийн үйлдвэр, нефть-хийн үйлдвэр, газар тариалан зэрэг олон салбарт хэрэглэж байна.

\section{Судалгааны арга зүй}

Дериватографийн шинжилгээг Унгарын Дрон-2 дериватограф дээр явуулсан ба 0.01 мм-ын шигшүүрээр шигшигдсэн 0.5 г судалгааны дээжийг керамик тигельд хийж багажинд байрлуулаад $\mathrm{T}=1000^{\circ} \mathrm{C}, \mathrm{DTA}-1 / 5 ; \mathrm{Vt}=10$ горимд бичлэгийг хийв. Дээжүүдийн дериватограмм дээр үндэслэн сул болон холбоот усны хэмжээг тодорхойлов. Тодорхой эзлэхүүнтэй саванд сул байдлаар асгаж хийсэн ширхэглэлтэй хуурай материалын эзлэхүүн жинг асгаасан нягт гэнэ. Доорх томъёогоор асгаасан нягтыг олно.

$$
P_{m}=\frac{m_{2}-m_{1}}{V}
$$

$\mathrm{m}_{1}$ - хоосон савны жин, г

$\mathrm{m}_{2}$ - хуурай бодистой савны жин, г

V- савны эзлэхүүн, мл 


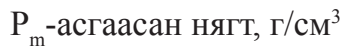

Дулаан боловсруулалтын судалгааг лабораторийн зууханд $1050-1250^{\circ} \mathrm{C}$ температурт $50^{0}$-ийн шатлалтайгаар перлитийн ширхэглэлээс хамааруулан явуулж хөөсөн перлит тус бүрийн асгаасан нягтыг хэмжиж хөөлтийн коэффициент тодорхойлов.

\section{Судалгааны дээжүүдийн дериватограммууд}

Перлитийн дулааны хөөлтөд нөлөөлөх гол үзүүлэлт болох чөлөөт болон холбоот усны хэмжээг дериватографийн аргаар судалж дээжүүдийн дериватограммуудыг төстэй байдлаар ангилав.
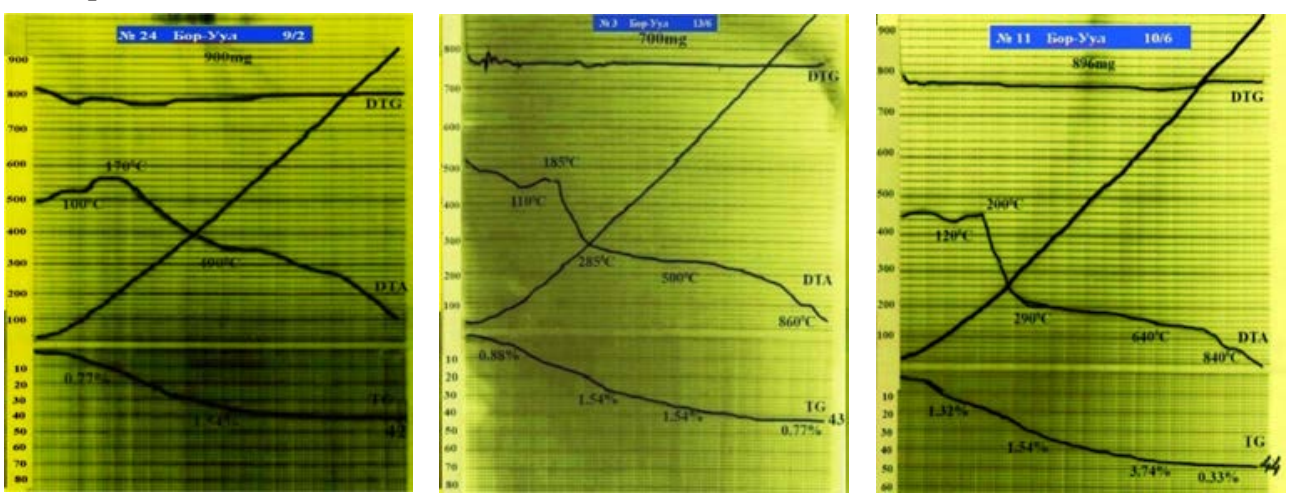

1-р зураг. №3, №24, №11 дээжүүдийн дериватограмм

№3, №11, №24 дугаартай дээжүүдийн дериватограммаас харахад чөлөөт усыг бага зэрэг агуулсан, сул холбоот усыг маш бага агуулсан байна. №3, №11 дээжүүдэд $850^{\circ} \mathrm{C}$ орчимд эндоэффект ажиглагдаж байгаа нь нягт холбоотой талстын ус агуулж буйг харуулж байна (1-р зураг).
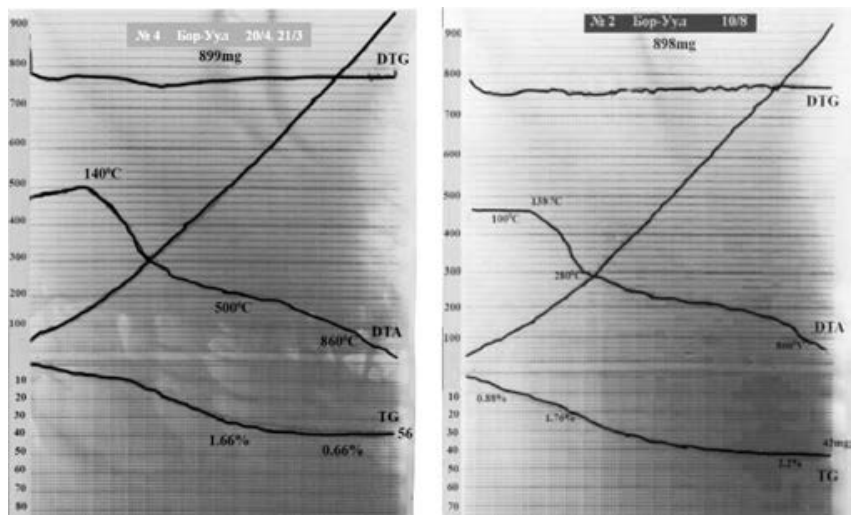

2-р зураг. №2, №4 дээжүүуийн дериватограмм

№2, №4 дээжүүдийн дериватограммаас харахад чөлөөт болон бүтцийн ус агуулаагүй, харин $860^{\circ} \mathrm{C}$-д $0.66 \%$ ба $2.2 \%$ жингийн бууралтанд харгалзах нягт холбоот талстын усны дэгдэлтээс шалтгаалсан эндоэффект үүссэн байна (2-р зураг). 


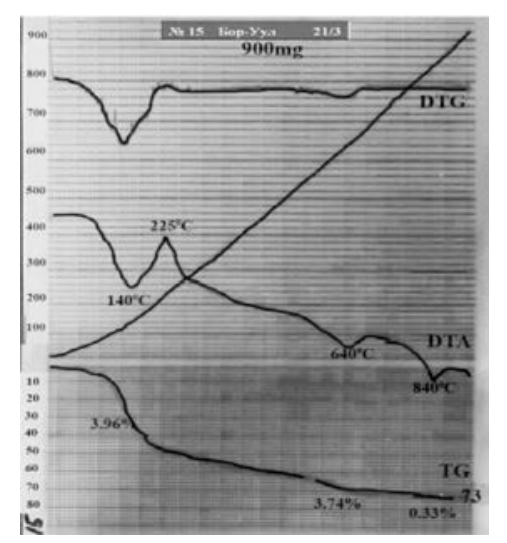

3-р зураг: №15 дээжийн дериватограмм

№15 дугаартай дээжний дериватограмм дээр $140^{\circ} \mathrm{C}$-д чөлөөт усны ууршилтаас үүссэн, $3.96 \%$ жингийн бууралтанд харгалзах эндоэффект үүссэн байгаа нь чөлөөт ус ихээр агуулдгийг харуулж байна. $640^{\circ} \mathrm{C}$-д гарсан эндоэффект дээр $3.74 \%$ жингийн бууралттай байгаа нь холбоот усыг мөн ихээр агуулдгийг харуулав. Иймээс дулааны хөөлт өндөр байх магадлалтай. $840^{\circ} \mathrm{C}$-д ажиглагдаж буй эндоэффект нь №15 дээж талстын ус агуулдгийг харуулж байгаа бөгөөд энэ үед $0.33 \%$ жингийн бууралттай байна(3-р зураг).

Перлитийн агаарын чийг болон шатаах үед гарах жингийн алдагдлыг $105,850^{\circ} \mathrm{C}$ температурт тодорхойлж үр дүнг дериватограмм дээрээс олсон үзүүлэлттэй харьцуулав.

Дээжний агаар дахь чийг $0.12-4.07 \%$ байхад $850^{\circ} \mathrm{C}$ дахь шатаалтын хорогдол 3.85$14.0 \%$ байгаа нь геологийн үүсэл тогтцоосоо шалтгаалан янз бүрийн эрдэс агуулсан дээж байгаатай холбон үзлээ. Перлит эрдэс дэх усны тоон үзүүлэлтийн талын мэдээллийг өгдөг термоанализ болох дериватографийн аргаар тодорхойлсон дүнг зууханд дулааны аргаар тодорхойлсон дүнтэй харьцуулахад тоон утга нь ойролцоо байгаа нь чөлөөт болон холбоот усны үзүүлэлтийг зөв гаргасныг харуулж байна.

1-р хүснэгт. Жингийн хорогдол ба дерватограммын УзҮүлэлтийг харьцуулах

\begin{tabular}{|c|c|c|c|c|c|c|}
\hline № & Цооног & $\begin{array}{c}\text { Нийт жингийн } \\
\text { алдагдал (\%) }\end{array}$ & $\begin{array}{l}\text { Чөлөөт } \\
\text { ус (\%) }\end{array}$ & $\begin{array}{c}\text { Холбоот } \\
\text { ус (\%) }\end{array}$ & 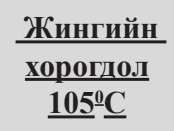 & $\frac{\text { Жингийн }}{\underline{\text { хорогдол }}} \frac{\underline{850}^{0} \underline{\mathrm{C}}}{}$ \\
\hline 1 & Ц-14/13. 15/2 & 5.58 & 2.2 & 3.08 & 1.23 & 4.91 \\
\hline 2 & Ц-10/8 & 5.12 . & 0.88 & 3.96 & 1.59 & 4.9 \\
\hline 3 & Ц-13/6 & 4.78 & 2.42 & 2.31 & 1.52 & 5.06 \\
\hline 4 & Ц-20/4. 21/3 & 4 & 0.66 & 3.3 & 0.82 & 4.08 \\
\hline 5 & $\begin{array}{l}\text { Ц-20/7. 21/9. 21/3. } \\
16 / 5.16 / 13\end{array}$ & 4.8 & 1.98 & 2.97 & 1.61 & 4.01 \\
\hline 6 & Ц-3/21. 4/14 & 5 & 2.61 & 2.58 & 1.25 & 14 \\
\hline 7 & Ц-19/15 & 4.77 & 1.2 & 2.66 & 1.7 & 4.97 \\
\hline 8 & Ц-23/16. 16/13 & 5.66 & 1.1 & 4.51 & 1.97 & 5.28 \\
\hline 9 & Ц-17/15 & 4.78 & - & 4.73 & 1.35 & 4.62 \\
\hline
\end{tabular}




\begin{tabular}{ll|c|c|c|c|c|}
\hline \hline 10 & Ц-14/2 & 4.68 & - & 4.62 & 1.11 & 4.47 \\
11 & Ц-10/6 & 5.35 & 2.86 & 2.42 & 1.52 & 4.54 \\
\hline 13 & Ц-5/14 & 5.55 & - & 5.5 & 1.77 & 5.3 \\
\hline 15 & Ц-21/3 & 8.11 & 3.96 & 4.07 & 4.08 & 8.04 \\
16 & Ц-12/2. 13/4 & 3.77 & & 3.74 & 1.05 & 3.85 \\
17 & Ц-15/15 & 4.4 & 1.1 & 3.3 & 1.85 & 4.38 \\
18 & Ц-16/5. 23/3 & 4.27 & 1.65 & 2.75 & 1.48 & 4.38 \\
19 & Ц-18/5. 19/9. 19/11 & 5.35 & - & 5.28 & 2.13 & 5.03 \\
\hline 20 & Ц-17/2. 17/4. 17/8 & 4.68 & - & 4.62 & 1.25 & 4.46 \\
\hline 21 & Ц-6/4. 8/3 & 6.22 & 2.2 & 3.96 & 3.21 & 6.78 \\
22 & Ц-22/3. 7/2 & 4.89 & - & 4.84 & 1.43 & 5.06 \\
\hline 23 & Ц-11/4 & 4.23 & - & 4.18 & 0.67 & 4.12 \\
\hline 24 & Ц-9/2 & 4.45 & 0.77 & 3.63 & 0.12 & 4.32 \\
25 & Ц-8/10 & 4.55 & 0.77 & 3.74 & 1.78 & 4.84 \\
\hline
\end{tabular}

1-р хүснэгтээс харахад холбоот ус нь 1-4\%, чөлөөт ус нь 2.66-5.5\% байгаа учраас судлагдсан дээжийг хоёрдогч эрдэс 10-20\% агуулж байх витротуф төрөлд оруулж болох юм. №5, №21 эдгээр дээжүүд нь сул гидратчилагдсан пемзо төрлийн перлитэд хамаарагдах зарим эндоэффект байгаа боловч эрчим нь багатайгаас гадна судлагдсан дээжүүдэд 320$340^{\circ} \mathrm{C}$ эндо эффектийн их байна. $120^{\circ} \mathrm{C}$ ба $320-360^{\circ} \mathrm{C}$ хоёр эндоэффектийн эрчим ихтэй № 24, 20,3,11 дээжүүдийн дериватограммыг бусад судлаачдын гарган авсан дериватограммын хэлбэртэй харьцуулах замаар судлагдсан дээжнүүд нь ерөнхий бага өөрчлөгдсөн гүн гидратчилагдсан перлит (№1,2,6,5,7,8,13,15,16,18,19), ян3 бүрийн өөрчлөлт болон талстажсан перлитийн (№ 3,2,20,24,22,19,25,17,9,10) төрөлд хамрагдах болохыг дериватограмм дээрээс тогтоов.

Перлитийн дулааны хөөлтийн судалгаанд 0.6-1.25мм, 1.25-3мм, 7-10мм ширхэглэлтэй фракцуудыг сонгон авав.

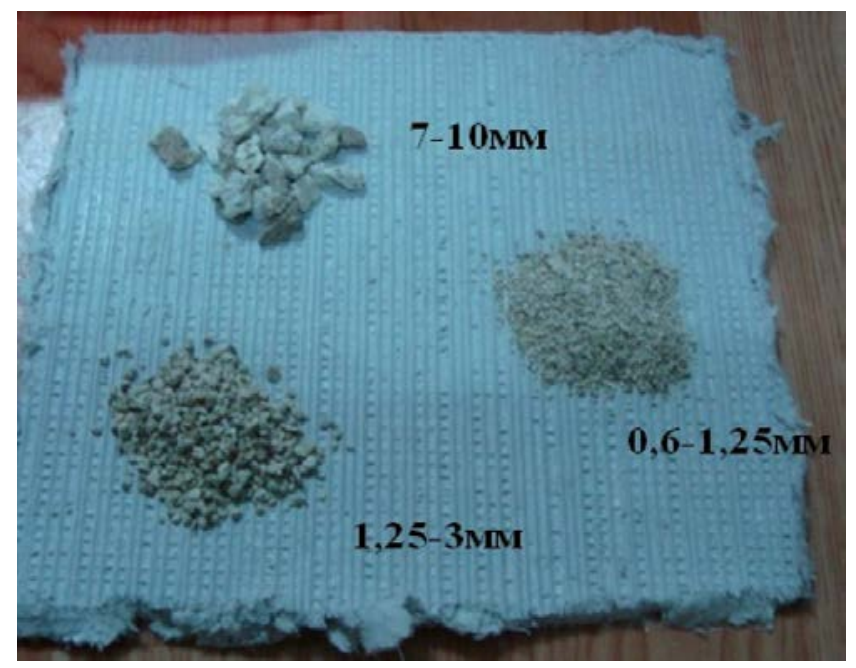

4-р зураг. Хөөлтийн судалгаанд сонгосон ширхэглэл 
Дээжүүдийн дериватограммыг үндэслэн 2-р хүснэгт дэх дээжүүдийг сонгож $250^{\circ} \mathrm{C}$ температурт Германы XL-105 зууханд 30 минут дулааны боловсруулалтанд урьдчилан оруулж хөөлтийн туршилтыг $1800^{\circ} \mathrm{C}$ гаргах стержийн зууханд $1100^{\circ} \mathrm{C}$ температурт тус бүр шатааж хөөлтийн коэффициентийг байгалийн перлиттэй нь харьцуулав.

2-р хүснэгт. $1100^{\circ} \mathrm{C}$ температурт 40секунд шатаасан перлитийн хөөлт

\begin{tabular}{|c|c|c|c|c|c|}
\hline № & Цооног & $\begin{array}{l}\text { Ширхэглэл } \\
\text { мм }\end{array}$ & $\begin{array}{c}\text { Урьдчилсан дулааны } \\
\text { боловсруулалт }\end{array}$ & $\begin{array}{c}\text { Асгаасан нягт } \\
\Gamma / \mathbf{c m}^{3}\end{array}$ & $\begin{array}{c}\text { Хөөлтийн } \\
\text { коэффициент }\end{array}$ \\
\hline \multirow{3}{*}{15} & \multirow{3}{*}{ Ц-21/3. } & $7-10$ & Үгүй & 0.25 & 3.47 \\
\hline & & $1.25-3$ & Үгүй & 0.350 & 2.68 \\
\hline & & $0.63-1.25$ & Үгүй & 0.338 & 2.88 \\
\hline 17 & Ц-15/15. & $1.25-3$ & Үгүй & 0.802 & 1.10 \\
\hline 3 & Ц-13/6. & $1.25-3$ & Үгүй & 0.798 & 1.18 \\
\hline 7 & Ц-19/15. & $1.25-3$ & Үгүй & 0.670 & 1.40 \\
\hline \multirow{3}{*}{15} & \multirow{3}{*}{ Ц-21/3. } & $7-10$ & $250^{\circ} \mathrm{C}$ & 0.317 & 2.73 \\
\hline & & $1.25-3$ & $250^{\circ} \mathrm{C}$ & 0.376 & 2.50 \\
\hline & & $0.63-1.25$ & $250^{\circ} \mathrm{C}$ & 0.405 & 2.40 \\
\hline 17 & Ц-15/15. & $1.25-3$ & $250^{\circ} \mathrm{C}$ & 0.742 & 1.19 \\
\hline 3 & Ц-13/6. & $1.25-3$ & $250^{\circ} \mathrm{C}$ & 0.784 & 1.20 \\
\hline 7 & Ц-19/15. & $1.25-3$ & $250^{\circ} \mathrm{C}$ & 0.735 & 1.28 \\
\hline
\end{tabular}

2-р хүснэгтээс үзэхэд перлитийг урьдчилан дулааны боловсруулалтанд оруулахад хөөлт буурж байгаа нь хөөлт явагдахад гол нөлөө үзүүлэх холбоот усны ууршилт $270-670^{\circ} \mathrm{C}-д$ явагдсанаар тайлбарлагдана. Мөн шатаалтын хугацааг ихэсгэхэд хөөлтийн коэффициент буурж байгаа нь хөөсөн перлит хайлж эхэлсэнтэй холбоотой.

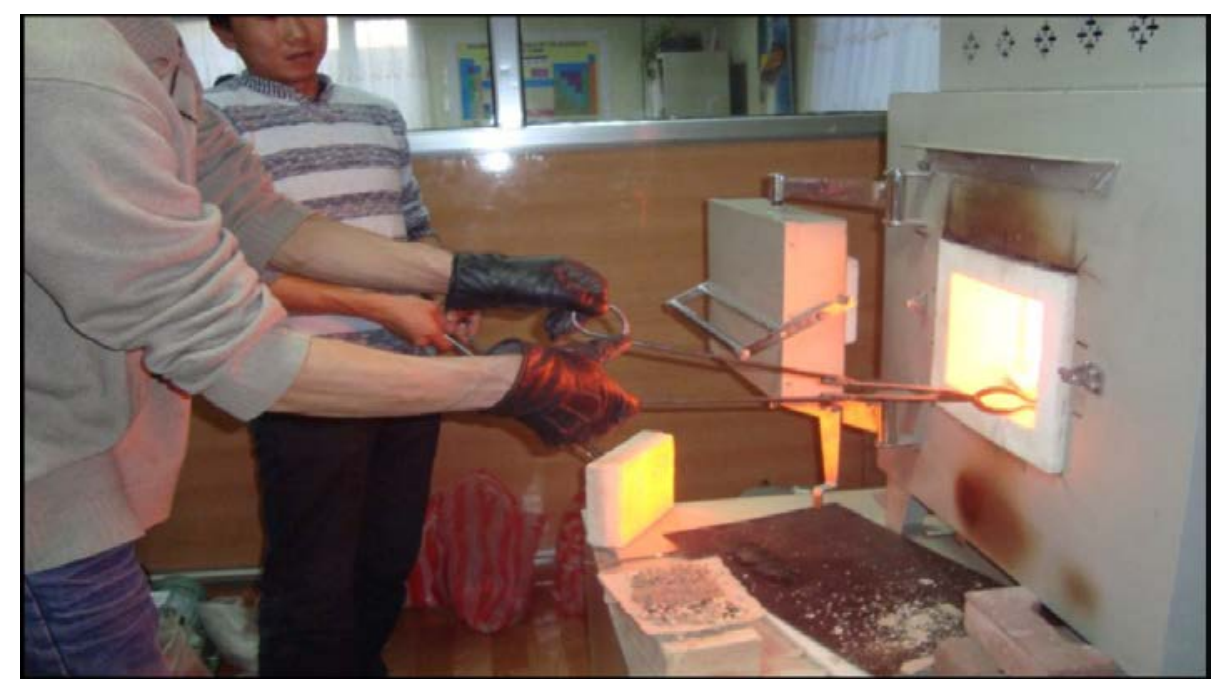

5-р зураг. 12000с температурт перлитийн дээж шатааж буй байдал 
40 секунд хугацаанд $1100^{\circ} \mathrm{C}, 1200^{\circ} \mathrm{C}$ температурт шатааж хөөлтийн коэффициент, асгаасан нягт тодорхойлж анхны асгаасан нягттай нь харьцуулав.

3-р хүснэгт. $1100^{\circ} \mathrm{c}, \mathbf{1 2 0 0}^{\circ} \mathrm{c}$ температурт 40сек шатаасан перлитүүдийн хөөлтийн коэффициент, асгаасан нягт

\begin{tabular}{|c|c|c|c|c|c|c|c|}
\hline \multirow[b]{2}{*}{ № } & \multirow[b]{2}{*}{ Цооног } & \multirow{2}{*}{$\begin{array}{c}\text { Ширхэглэл } \\
\text { мм }\end{array}$} & \multicolumn{2}{|c|}{$1100^{\circ} \mathrm{C}$} & \multicolumn{2}{|c|}{$1200^{\circ} \mathrm{C}$} & \multirow{2}{*}{$\begin{array}{c}\text { Байгаль } \\
\text { Асгаасан } \\
\text { нягт, г/см }\end{array}$} \\
\hline & & & 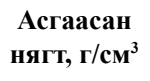 & $\begin{array}{l}\text { Хөөлтийн } \\
\text { коэф }\end{array}$ & 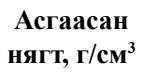 & $\begin{array}{l}\text { Хөөлтийн } \\
\text { коэф }\end{array}$ & \\
\hline \multirow{3}{*}{4} & \multirow{3}{*}{$20 / 4.21 / 3$} & $0.6-1.25$ & 0.566 & 1.801 & 0.61 & 1.673 & 1.021 \\
\hline & & $1.25-3$ & 0.502 & 1.97 & 0.516 & 1.914 & 0.989 \\
\hline & & 7-10. & 0.528 & 1.65 & 0.618 & 1.411 & 0.873 \\
\hline \multirow{3}{*}{6} & \multirow{3}{*}{$3 / 21.4 / 14$} & $0.6-1.25$ & 0.834 & 1.124 & 0.747 & 1.255 & 0.938 \\
\hline & & $1.25-3$ & 0.834 & 1.156 & 0.792 & 1.217 & 0.964 \\
\hline & & $7-10$ & 0.728 & 1.176 & 0.714 & 1.199 & 0.857 \\
\hline \multirow{3}{*}{13} & \multirow{3}{*}{$5 / 14$} & $0.6-1.25$ & 0.662 & 1.404 & 0.779 & 1.194 & 0.93 \\
\hline & & $1.25-3$ & 0.628 & 1.501 & 0.76 & 1.24 & 0.943 \\
\hline & & $7-10$ & 0.65 & 1.271 & 0.693 & 1.192 & 0.826 \\
\hline \multirow{3}{*}{15} & \multirow{3}{*}{$21 / 3$} & $0.6-1.25$ & 0.688 & 1.416 & 0.547 & 1.781 & 0.975 \\
\hline & & $1.25-3$ & 0.589 & 1.597 & 0.416 & 2.262 & 0.941 \\
\hline & & $7-10$ & 0.494 & 1.754 & 0.409 & 2.118 & 0.868 \\
\hline \multirow{3}{*}{16} & \multirow{3}{*}{$12 / 2.13 / 4$} & $0.6-1.25$ & 0.755 & 1.237 & 0.696 & 1.342 & 0.935 \\
\hline & & $1.25-3$ & 0.735 & 1.318 & 0.697 & 1.389 & 0.97 \\
\hline & & $7-10$ & 0.709 & 1.231 & 0.665 & 1.312 & 0.872 \\
\hline \multirow{3}{*}{18} & \multirow{3}{*}{$16 / 5,23 / 3$} & $0.6-1.25$ & 0.8 & 1.192 & 0.714 & 1.335 & 0.953 \\
\hline & & $1.25-3$ & 0.793 & 1.256 & 0.717 & 1.388 & 0.996 \\
\hline & & 7-10. & 0.752 & 1.194 & 0.729 & 1.231 & 0.898 \\
\hline \multirow{3}{*}{21} & \multirow{3}{*}{$6 / 4.8 / 3$} & $0.6-1.25$ & 0.88 & 1.105 & 0.88 & 1.105 & 0.972 \\
\hline & & $1.25-3$ & 0.713 & 1.404 & 0.783 & 1.279 & 1.002 \\
\hline & & $7-10$ & 0.688 & 1.204 & 0.852 & 0.974 & 0.829 \\
\hline \multirow{3}{*}{20} & \multirow{3}{*}{$17 / 2.17 / 4.17 / 8$} & $0.6-1.25$ & 0.789 & 1.206 & 0.745 & 1.278 & 0.952 \\
\hline & & $1.25-3$ & 0.648 & 1.539 & 0.69 & 1.445 & 0.998 \\
\hline & & $7-10$ & 0.573 & 1.488 & 0.669 & 1.273 & 0.853 \\
\hline \multirow{3}{*}{22} & \multirow{3}{*}{$22 / 3.7 / 2$} & $0.6-1.25$ & 0.745 & 1.286 & 0.696 & 1.377 & 0.959 \\
\hline & & $1.25-3$ & 0.786 & 1.198 & 0.744 & 1.266 & 0.942 \\
\hline & & $7-10$ & 0.783 & 0.997 & 0.717 & 1.088 & 0.781 \\
\hline
\end{tabular}

Хөөлтийн коэффициент өндөртэйг харгалзан №16 ( Ц-12/2+Ц-13/4), дээжийг $1200^{\circ} \mathrm{C}$ температурт хугацаанаас хамааруулан 20, 40, 120, 180, 240 секундэд шатааж хөөлтийн коэффициент, асгаасан нягтыг тус бүр тодорхойлж 4-р хүснэгтээр үзүүлэв. 
4-р хүснэгт. №16 дээжийн $1200^{\circ} \mathrm{C}$ температурын хөөлт ба хугацааны хамаарал

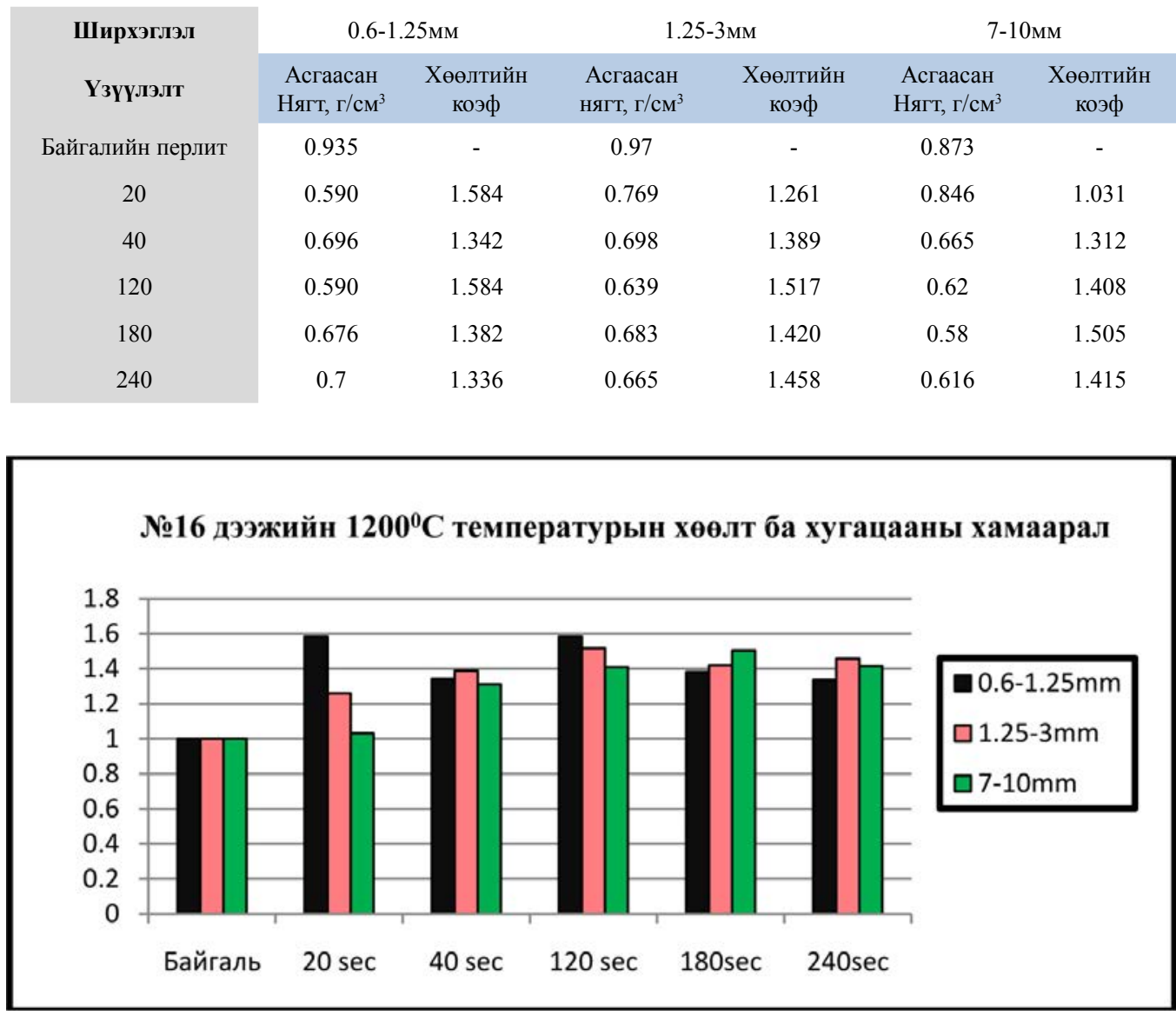

Мөн хөөлтийн коэффициент өндөртэйг харгалзан №15 (Ц-21/3) дээжийг 40сек хугацаанд температураас хамааруулан $1050^{\circ} \mathrm{C}, 1100^{\circ} \mathrm{C}, 1150^{\circ} \mathrm{C}, 1200^{\circ} \mathrm{C}, 1250^{\circ} \mathrm{C}$ температурт шатааж асгаасан нягтыг хэмжиж хөөлтийн коэффициентыг тооцоолов( 5-р хүснэгт).

\section{5-р хүснэгт. №15 дээжийн хөөлт ба температурын хамаарал (40сек)}

\begin{tabular}{|c|c|c|c|c|c|c|}
\hline \multirow{2}{*}{$\begin{array}{l}\text { Ширхэглэл } \\
\text { Үзүүлэлт }\end{array}$} & \multicolumn{2}{|c|}{$0.6-1.25 \mathrm{MM}$} & \multicolumn{2}{|c|}{$1.25-3 \mathrm{Mm}$} & \multicolumn{2}{|c|}{ 7-10мM } \\
\hline & 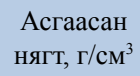 & $\begin{array}{c}\text { Хөөлтийн } \\
\text { коэф }\end{array}$ & 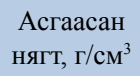 & $\begin{array}{c}\text { Хөөлтийн } \\
\text { коэф }\end{array}$ & 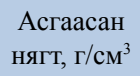 & $\begin{array}{c}\text { Хөөлтийн } \\
\text { коэф }\end{array}$ \\
\hline Байгалийн перлит & 0.975 & - & 0.9415 & - & 0.868 & - \\
\hline $1050^{\circ} \mathrm{C}$ & 0.7 & 1.393 & 0.591 & 1.593 & 0.657 & 1.32 \\
\hline $1100^{\circ} \mathrm{C}$ & 0.689 & 1.416 & 0.589 & 1.597 & 0.494 & 1.75 \\
\hline $1150^{\circ} \mathrm{C}$ & 0.491 & 1.987 & 0.46 & 2.046 & 0.494 & 1.75 \\
\hline $1200^{\circ} \mathrm{C}$ & 0.547 & 1.781 & 0.416 & 2.262 & 0.409 & 2.11 \\
\hline $1250^{\circ} \mathrm{C}$ & 0.5 & 1.951 & 0.436 & 2.16 & 0.375 & 2.31 \\
\hline
\end{tabular}




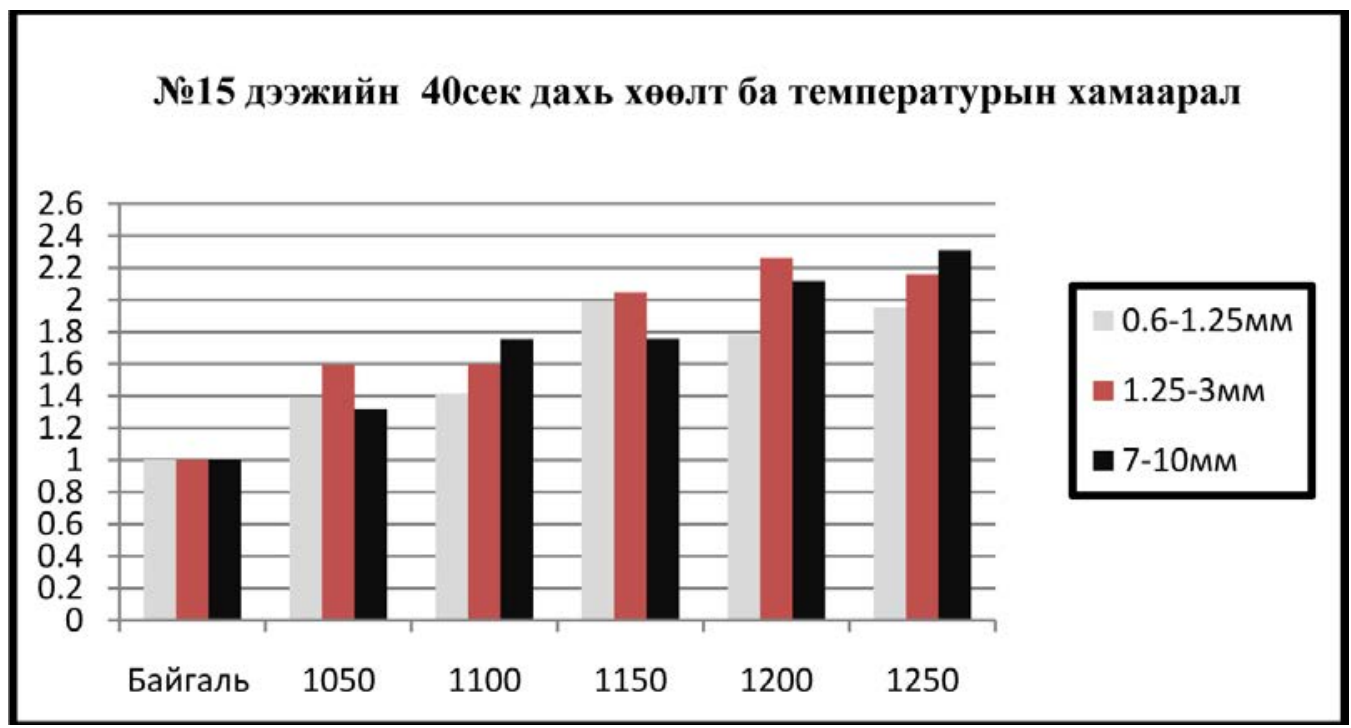

5-p хүснэгтээс харахад дулааны боловсруулалт хийх температурын зөрүү $50^{\circ} \mathrm{C}$ байхад зарим дээжний эзлэхүүн жингийн бууралтын өөрчлөлт мэдэгдэхүйц байсан ба уг өөрчлөлтийг перлит дэх эрдэс бүрэлдэхүүн, хольц хэлбэрээр орших эрдсүүдтэй холбон үзлээ. Дээрх туршилтууд дээр үндэслэн тасалгаат зууханд шатаах перлитийн хөөлтийн зохистой горимыг тогтоов.

6-р хүснэгт. Перлитийн хөөлтийн зохистой горим

\begin{tabular}{|c|c|c|c|}
\hline Ширхэглэл & Хөөлтийн температур & Хөөлтийн хугацаа & $\begin{array}{c}\text { Хамгийн их хөөлтийн } \\
\text { итгэлцүүр }\end{array}$ \\
\hline $0.6-1.25 \mathrm{~mm}$ & $1150^{\circ} \mathrm{C}$ & $120 \mathrm{ce \kappa}$ & 1.987 \\
$1.25-3 \mathrm{~mm}$ & $1200^{\circ} \mathrm{C}$ & $40 \mathrm{ce \kappa}$ & 2.262 \\
$7-10 \mathrm{~mm}$ & $1200^{\circ} \mathrm{C}$ & $180 \mathrm{ce \kappa}$ & 1.505 \\
\hline
\end{tabular}

Перлитийн хөөлгөх технологи, шатаах зуухны төрөл байдлаас үзэхэд түүхий эдийг тал бүрээс нь жигд халаах нөхцөлийг бүрдүүлэхэд перлит сайн хөөж байгаа нь тогтоогдсон учир өөрсдийн нөхцөл бололцоог ашиглан буцлах үетэй төхөөрөмжийг кварц шил ашиглан зохион бүтээж хөөлтийн судалгааг явуулав.

Гүн гидратчилагдсан төрлийн перлитийн дээжний төлөөлөл болгон №15 дээжээс нунтаг байдлаар авч хөөлгөх судалгааг буцлах үетэй босоо хэлбэрийн төхөөрөмж дээр явуулахад 1.1286 г $\mathrm{cm}^{3}$ эзлэхүүн жинтэй нунтаг дээж хөөлгөсний дараa $0.114 \Gamma / \mathrm{cm}^{3}$ эзлэхүүн жинтэй болж 9.4 дахин хөөж гадаргуугаараа сувд шиг гялгар хөвсгөр цагаан болов. 


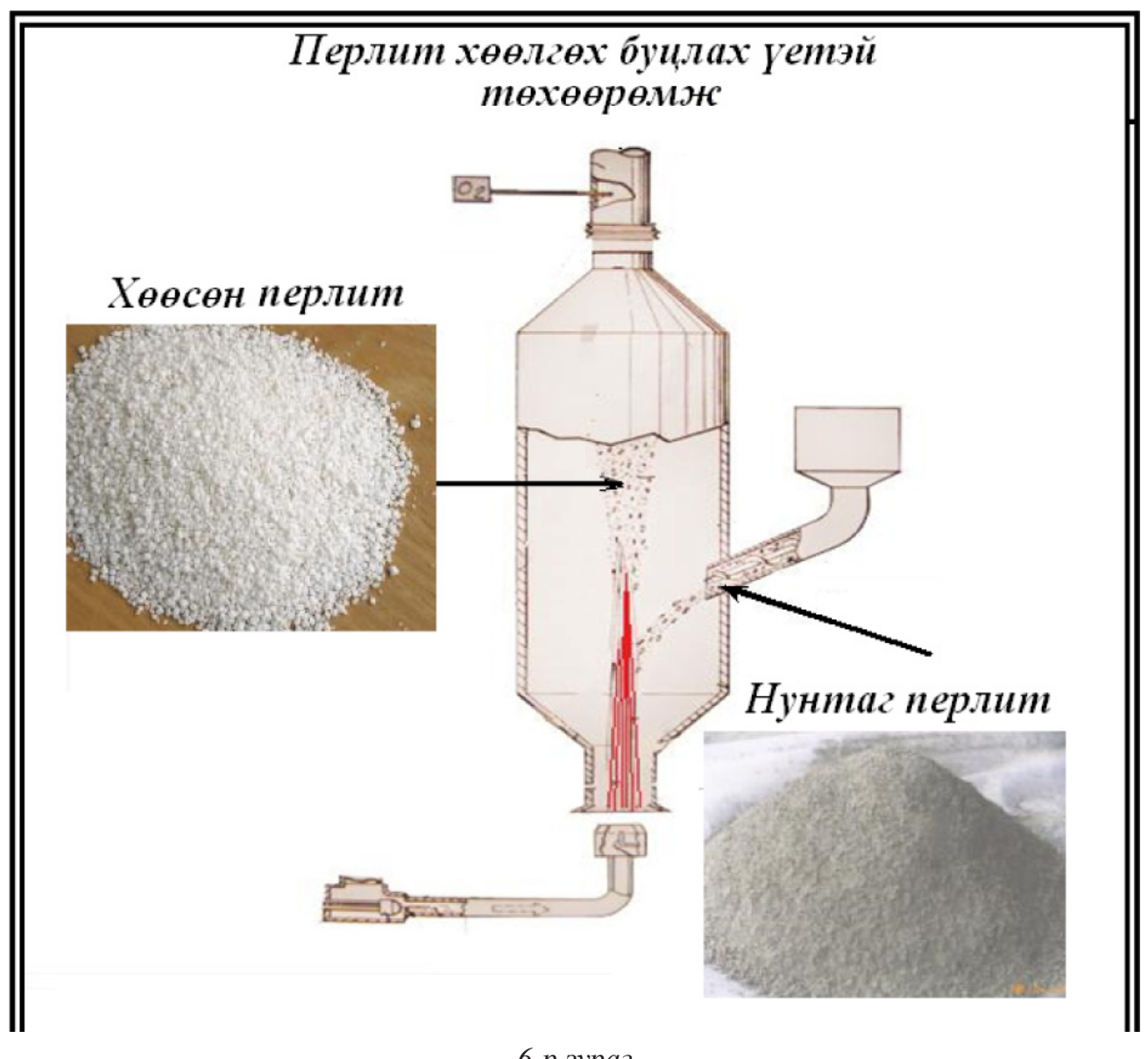

6-р зураг

\section{Дүгнэлт}

1. Перлитийн хөөлтийн судалгаанд урьдчилан $250^{\circ} \mathrm{C}-д$ дулааны боловсруулалтанд оруулахад гүн гидратчилагдсан төрлийн перлитэн эдлэлийн гадаргуугийн ан цав буурах боловч чөлөөт усны ууршилтаас шалтгаалан хөөлтийн коэффициент буурж буйг тогтоов.

2. Лабораторийн шахаах зууханд хөөлтийн судалгааг $1050-1250^{\circ} \mathrm{C}-д$ явуулж хөөсөн перлитийн асгаасан нягтыг хэмжиж хөөлтийн коэффициентыг олоход 0.974- 2.31 байв. Эдгээр туршилт дээр үндэслэн Төв аймгийн Баян сумын Бор-Уулын ордын перлитийн хөөлтийн зохистой горимыг тухайн нөхцөлд тодорхойлов.

3. Буцлах үетэй босоо хэлбэрийн төхөөрөмжид перлитийн нунтаг дээж ашиглан хөөлтийн судалгааг явуулснаар судалгаа хийгдсэн дээжүүд 9.4 дахин хөөж болохыг туршилтаар тогтоов. 


\section{Ном зүй}

1. Перлитовая промышленность. Развития и размещение. 1980

2. Перлиты. 1981

3. Подлесный.В.С, Гусейнов.Э.А, Сергеев.Н.И. Совершенствование технологии производства вспученного щебия и песка из перлита и других вулканических пород.В ки: Перспекивы развития произодства и применения легких бетонов и конструкций из них. М: Госстройиздат, 1978.

4. Хөөсөн перлитийн элс, дайрга. Техникийн шаардлага Стандартын тэмдэглэгээ : MNS 5608 - 2006 5x

5. Х Хөөсөн перлит үйлдвэрлэхэд хэрэглэх түүхий эд. Техникийн шаардлага. Стандартын тэмдэглэгээ : MNS 5609 - 2006 8x

6. Перлитийг хөөлгөж дулаан тусгаарлагч материал үйлдвэрлэх технологи (Б.Аръяадагва, Л.Нацаг 1961-1962 он).

7. Б.Лхагва. Монгол орны эрдэс түүхий эд ашиглан шинэ материал үйлдвэрлэх технологи. 2001 он 